\title{
Modelling the Cervical Cancer Growth Process by Stochastic Delay Differential Equations
}

(Pemodelan Proses Pertumbuhan Kanser Serviks oleh Persamaan Pembezaan Stokastik Lengahan)

\author{
MAZMA SYAHIDATUl AYUNi MAZLAN, NORHAYATI ROSLI*, NinA SUHAITY AZMI \& ARIFAH BAHAR
}

\begin{abstract}
In this paper, the uncontrolled environmental factors are perturbed into the growth rate deceleration factor of the Gompertzian deterministic model. The growth process under Gompertz's law is considered, thus lead to stochastic differential equations of Gompertzian with time delay. The Gompertzian deterministic model has proven to fit well with the clinical data of cancerous growth, however the performance of stochastic model towards clinical data is yet to be confirmed. The prediction quality of stochastic model is evaluated by comparing the simulated results with the clinical data of cervical cancer growth. The parameter estimation of stochastic models is computed by using simulated maximum likelihood method. 4-stage stochastic Runge-Kutta is applied to simulate the solution of stochastic model. Low values of root mean-square error (RMSE) of Gompertzian model with random effect indicate good fits.
\end{abstract}

Keywords: Gompertzian model; simulated maximum likelihood; stochastic delay differential equation; 4-stage stochastic Runge Kutta

ABSTRAK

Kertas kerja ini mempertimbangkan faktor persekitaran tidak terkawal yang diganggu ke atas faktor penurunan kadar pertumbuhan model Gompertzian berketentuan. Proses pertumbuhan di bawah hukum Gompertz dipertimbangkan, seterusnya membawa kepada persamaan pembezaan stokastik Gompertzian dengan masa lengahan. Model Gompertzian berketentuan telah terbukti sesuai untuk data klinikal pertumbuhan kanser, walau bagaimanapun keberkesanan model stokastik terhadap data klinikal masih belum disahkan. Kualiti ramalan model stokastik dinilai dengan membandingkan keputusan simulasi dengan data klinikal pertumbuhan kanser pangkal rahim. Anggaran parameter model stokastik dikira dengan meng gunakan kaedah simulasi kebolehjadian maksimum. Stokastik Runge-Kutta peringkat 4 diaplikasikan untuk mencari penyelesaian simulasi model stokastik. Nilai punca min ralat kuasa dua (RMSE) yang rendah bagi model Gompertzian dengan kesan rawak menunjukkan keputusan yang baik.

Kata kunci: Model Gompertzian; persamaan pembezaan stokastik dengan masa lengahan; simulasi kebolehjadian maksimum; stokastik Runge Kutta peringkat 4

\section{INTRODUCTION}

National Cancer Society Malaysia (NCSM) stated that an average of 1500 is diagnosed with cervical cancer every year, with the majority of cases presenting at the late stages of the diseases (Mohamed 2013). The National Cancer Institute (NCI) reported that cervical cancer growth usually develops slowly over time. Prior to the development of cervical cancer, the cells of the cervix go through the process that change the cervical cells. It is known as dysplasia or cervical intraepitherial neoplasia (CIN), in which cells on the surface of the cervix can appear abnormal in the cervical tissue. Later, cancer cells start to grow and spread into the deeper layers of the cervix and to the surrounding areas (American Cancer Society 2014).

Recently, many mathematical formulations offer a wide range of biological study that can be classified regarding to the precise tumor growth rate or the pattern of tumor growth in order to improve a better treatment strategies or at least to improve the patient's quality life. Many mathematical models of cancerous growth have ignored the presence of random variations. The uncontrolled factors cannot be neglected since cancerous growth are subjected to this effect. The presence of noise in mathematical model is therefore required. It reflects the actual behavior of cancerous growth and implies a cancer clone may regress prior reaching a detectable size. Moreover, noise is not completely understood in deterministic model, hence not feasible to model deterministically (Ferrante et al. 2000). To be realistic, mathematical models of a biological system should include noise or stochasticity. In fact, stochastic model has recently been used as an effective tool in understanding the dynamic behavior of cancer progression and metastasis formation. Most studies used a stochastic version that based on Gompertz law to account for random fluctuations of the model parameters. They assumed that the growth deceleration factors do not change and the variability of environmental conditions only induces fluctuations in the intrinsic growth rate (Ferrante et 
al. 2000; Lo 2007; Mazma Syahidatul Ayuni \& Norhayati 2014).

However, individual cancer cells are not immortal. Death of cancer cells occurs through the process of apoptosis or necrosis (Lowe \& Lin 2000). The competition might occur between the cancer cells for their growth and survival that may lead to the presence of stochasticity. The latter happened due to insufficient supply of nutrient or excessive accumulation of metabolic waste products. The cancer cells may also be killed by the immune system of the human body.

Next, the Gompertzian stochastic model has been constructed and contributed in its own way to a better understanding in vivo tumor growth (Ferrante et al. 2000) and cervical cancer growth (Mazma Syahidatul Ayuni \& Norhayati 2014). In a real situation, the dynamical behavior of cancer cell growth rate depends on its structure at the present time and it also takes into account the structure at some previous time (Byrne 1997). Therefore, the presence of time delay into Gompertzian stochastic model is required in order to predict the realistic behaviour of cervical cancer growth development. By taking into account the stochastic effect and delayed-feedback, it is indispensable to model the cervical cancer growth via stochastic delay differential equations (SDDEs).

This paper is organized as follows; the next section presents a Gompertzian stochastic model with time delay for cervical cancer growth. In the following section, numerical solution and parameter estimation of stochastic model with delay effects is performed. Then, the simulated results of the mathematical model and clinical data of cancerous growth are plotted and the root mean-square error is measured. Finally, the last section offers a brief discussion and some concluding remarks.

\section{MathematicAl MODEL}

The deterministic mathematical model of cancer growth has been introduced by Laird (1964). It is based on Gompertz's law and has been shown to fit and explain the cancerous growth successfully. It has the form of:

$$
\frac{d A}{d t}=a A(t)-b A(t) \ln (A(t))
$$

where $A(t)$ denotes the area of the tumor at time $t, a$ is intrinsic growth rate of the tumor which correspond to the initial mitosis rate and $b$ represents the growth rate deceleration factor that describes the antiangiogenic process. In oncology, the deterministic Gompertzian model (1) appears to be useful in describing the cancerous growth. Despite their simplicity, the mathematical model of cancerous growth (1) should include random effects or noise that influence cancerous growth behavior. A stochastic version of the Gompertzian deterministic model can be developed by assuming that the growth rate deceleration factor varies in time according to:

$$
-b \rightarrow-b+\sigma \frac{d W}{d t},
$$

where $\sigma>0$ is the diffusion coefficient and the process $d W$ being a Gaussian white noise process with mean zero and variance, $\Delta t$. Thus, the mathematical model for cancerous growth can be defined by the stochastic differential equation (SDE) of

$$
\begin{aligned}
d A(t)= & (a A(t)-b A(t) \ln A(t)) \\
& d t+\sigma A(t) \ln A(t) d W(t) .
\end{aligned}
$$

Mathematical model of SDE under Gompertz law has been used to model in vivo tumor growth (Ferrante et al. 2000) and cervical cancer growth (Mazma Syahidatul Ayuni \& Norhayati 2014). However, the stochastic model of cancerous growth only depends on the structure at the present time. In fact, the dynamical behavior of cancerous growth not only relies on the structure of its growth at some present time but also depend on the structure at some previous time (Byrne 1997). Thus, Gompertzian stochastic model should include the delayed feedback. Time delay, $r$ is introduced into growth rate deceleration factor and (3) is modified which evolves according to the stochastic Gompertzian model with delay effects

$$
\begin{aligned}
d A(t)= & (a A(t)-b A(t-r) \ln A(t)) \\
& d t+\sigma A(t) \ln (A(t)) d W(t) .
\end{aligned}
$$

Next, the Gompertzian stochastic model with time delay (4) will be used to describe the growth of cervical cancer. This research is also verifying the ability of the Gompertzian stochastic model to simulate the clinical data.

\section{NUMERICAL METHOD}

The analytical solution of Gompertzian stochastic model with delay effects (4) is hard to be solved, thus numerical method is used to approximate the strong solution of SDDEs. In this paper, we apply a 4-stage Stochastic Runge-Kutta (SRK4) to simulate the numerical solution of Gompertzian stochastic model with time delay of (4). SRK method is a derivative-free and does not need computation of derivative for drift and diffusion function. The convergence of SRK method proposed by Norhayati (2012) improves the order of convergence rate of numerical approximation of SDDES since time delay and stochastic in a mathematical model is considered. General formulation of SRK method for SDDE has been proposed by Norhayati (2012) and it can be written as:

$$
\begin{aligned}
Y_{i}^{(n-m)}(t)= & Y\left(t_{0}\right)+\sum_{j=1}^{s} Z_{i j}^{(0)} f\left(Y_{j}^{(n-m)}(t), Y_{j}^{(n-2 m)}(t)\right) \\
& +\sum_{j=1}^{s} Z_{i j}^{(1)} g\left(Y_{j}^{(n-m)}(t)\right)
\end{aligned}
$$




$$
\begin{gathered}
Y_{i}^{(n)}(t)=Y\left(t_{0}\right)+\sum_{j=1}^{s} Z_{i j}^{(0)} f\left(Y_{j}^{(n)}(t), Y_{j}^{(n-m)}(t)\right) \\
+\sum_{j=1}^{s} Z_{i j}^{(1)} g\left(Y_{j}^{(n)}(t)\right) \\
y(t)=y\left(t_{0}\right)+\sum_{j=1}^{s} z_{i}^{(0)} f\left(Y_{j}^{(n)}(t), Y_{j}^{(n-m)}(t)\right) \\
+\sum_{j=1}^{s} z_{i}^{(1)} g\left(Y_{i}^{(n)}(t)\right),
\end{gathered}
$$

where, $Z_{i j}^{(0)}, Z_{i j}^{(1)}, z_{i}^{(0)}$ and $z_{i}^{(1)}$ written as follows:

$$
\begin{array}{ll}
Z_{i j}^{(0)}=\Delta a_{i j} & i, j=1, \ldots, s . \\
Z_{i j}^{(1)}=\sum_{l=1}^{q} b_{i j}^{(l)} \theta_{l}, & i, j=1, \ldots, s . \\
z_{i}^{(0)}=\Delta \alpha_{i}, & i, j=1, \ldots, s . \\
z_{i}^{(0)}=\sum_{l=1}^{q} \gamma_{i}^{(l)} \theta_{l}, & i, j=1, \ldots, s .
\end{array}
$$

For $q=2$, then $\theta_{1}=J_{1}$ and $\theta_{2}=\frac{J_{10}}{h}$, where $J_{1}=$ $\int_{t_{n}}^{t_{n+1}} d W(s) d t$ and $J_{10}=\int_{t_{n}}^{t_{n+1}} \int_{t_{n}}^{t} d W(s) d t$. Random variables $J_{1}$ and $J_{10}$ is approximated by using:

$$
\begin{aligned}
& J_{1}=\sqrt{h} N_{1} \\
& \frac{J_{10}}{h}=\frac{\sqrt{h}}{2}\left(N_{1}+\frac{N_{2}}{\sqrt{3}}\right),
\end{aligned}
$$

where $N_{1}$ and $N_{2}$ are standard normal distribution. Therefore, $s$ - stage SRK is written as:

$$
\begin{aligned}
& Y_{i}^{(n-m)}(t)= Y\left(t_{0}\right)+\Delta \sum_{j=1}^{s} a_{i j}^{(0)} f\left(Y_{j}^{(n-m)}(t), Y_{j}^{(n-2 m)}(t)\right) \\
&+\sum_{j=1}^{s}\left(b_{i j}^{(1)} J_{1}+b_{i j}^{(2)} \frac{J_{10}}{h}\right) g\left(Y_{i}^{(n-m)}(t)\right) \\
& Y_{i}^{(n)}(t)= Y\left(t_{0}\right)+\Delta \sum_{j=1}^{s} a_{i j}^{(0)} f\left(Y_{j}^{(n)}(t), Y_{j}^{(n-m)}(t)\right) \\
&+\sum_{j=1}^{s}\left(b_{i j}^{(1)} J_{1}+b_{i j}^{(2)} \frac{J_{10}}{h}\right) g\left(Y_{i}^{(n)}(t)\right) \\
& y(t)=y\left(t_{0}\right)+\Delta \sum_{j=1}^{s} \alpha_{i}^{(0)} f\left(Y_{j}^{(n)}(t), Y_{j}^{(n-m)}(t)\right) \\
&+\sum_{j=1}^{s}\left(\gamma_{i}^{(1)} J_{1}+\gamma_{i}^{(2)} \frac{J_{10}}{h}\right) g\left(Y_{i}^{(n)}(t)\right) .
\end{aligned}
$$

4-stage SRK scheme for SDDEs with strong order 1.5 has been developed in Norhayati (2012) and numerical scheme is represented in table form:
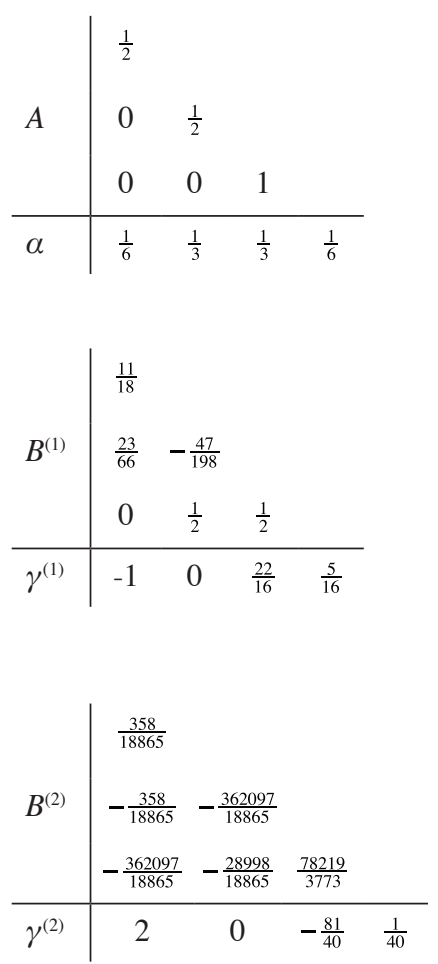

This numerical scheme was translated into $\mathrm{C}$ program and the strong solution of SDDE (4) for cervical cancer growth is simulated. Numerical algorithm is presented as:

Define the fixed step-size, $\Delta=\frac{T}{N}, t_{n}=(n-1) \Delta$, for $n=1, \ldots$, $N$; Define an integer number $N_{r}$ such that the delay can be expressed in terms of the step size $r=N_{r} \Delta$; Define the step, such as the step is step $=\frac{T}{r}$; Evaluate initial function $\Phi([$ step $][n-1])$ at the initial interval $t \in[-r, 0]$; Print the solution $y(t)=\Phi([$ step $][n-1]$ for $t \in[-r, 0]$; Evaluate drift function, $f$; If $s t e p=1$, the drift function is $f(y[$ step $]$ $[n-1], \Phi([$ step $][n-1]))$ else the drift function is computed as $f\left(y[\right.$ step $][n-1], y[$ step $\left.]\left[(n-1)-N_{r}\right]\right)$; Evaluate diffusion function, $g(y[$ step $][n-1])$; Generate a random number generator, $r a n d n$; and Perform an explicit SRK4 of order 1.5.

\section{PARAMETER ESTIMATION}

Most of the parameter estimation methods for SDDEs were developed for SDDEs with additive noise and no delay in diffusion. Estimation method for SDDEs with multiplicative noise was proposed by Guillouzic et al. (1999). However, it is applicable for SDDEs with small delay only. Since time delay in cancerous growth is considerably small (Friberg \& Mattson 1997), we adopt a method proposed by Guillouzic et al. (1999) to estimate the kinetic parameter of SDDE (4). The drift and diffusion functions in (4) are expanded using Taylor series around $A(t)$ and only terms up to first order in $d t$ are kept. SDDE (4) can be reduced to the SDE 


$$
d A=f_{a}(A) d t+\sigma g_{a}(A) d W(t)
$$

where

$$
f_{a}\left(A_{0}\right) \equiv f\left(A_{0}, A_{0}\right)\left(1-r \frac{\partial}{\partial A_{r}} f\left(A_{0}, A_{0}\right)\right)
$$

and

$$
g_{a}\left(A_{0}\right) \equiv g\left(A_{0}\right)\left(1-r \frac{\partial}{\partial A_{r}} f\left(A_{0}, A_{0}\right)\right),
$$

for $\left.\frac{\partial}{\partial A_{r}} f\left(A_{0}, A_{0}\right) \equiv \frac{\partial}{\partial A_{r}} f\left(A_{0}, A_{r}\right)\right|_{A_{r}=A_{0}}$. By applying (10) and (11) to drift and diffusion functions in (9), yields

$$
\begin{aligned}
d A= & \left(a A_{0}-b A_{0} \ln A_{0}\right)(1+r b) d t+\sigma A_{0} \ln A_{0} \\
& (1+r b) d W(t) .
\end{aligned}
$$

Non-parametric simulated maximum likelihood approach is applied to estimate the unknown parameters of Gompertzian stochastic model with delay effects.

\section{RESULTS AND DISCUSION}

This section presents the simulated results of the Gompertzian stochastic model with delay effects to the cervical cancer growth. To validate the effectiveness of (4) in describing the cancerous growth, we compare the simulated results with the clinical data. The cancer data was taken from Hospital Sultanah Nur Zahirah (HSNZ) Kuala Terengganu. A 48 year-old woman diagnosed with cervical cancer and without having any treatment from HSNZ was identified. The approval letter was obtained from research committee of Jabatan Kesihatan Negeri Terengganu [reference number: JKNT.TR:600-12Jld 4(25)].

The measured variables were time (in months) and area of cervical cancer cell (in $\mathrm{cm}^{2}$ ). Initial condition is the area of cervical cancer at time that it was first detected. The estimated kinetic parameter values of are listed in Table 1. The results of the models are shown in Figure 1.

\section{CONCLUSION}

The numerical solution of Gompertzian stochastic model

\begin{tabular}{|c|c|c|c|c|}
\hline Mathematical model & $a$ & $b$ & $\sigma$ & $r$ \\
\hline Gompertzian stochastic model with delay effects & $9.67349 e-001$ & $-1.866746 \mathrm{e}+000$ & $6.18038 e 3-001$ & 1 \\
\hline Gompertzian stochastic model & $9.288110 e-001$ & $-2.000000 e-000$ & $7.602268 e-001$ & - \\
\hline Gompertzian deterministic model & $1.043000 e+000$ & $-0.074800 e+000$ & - & - \\
\hline
\end{tabular}
with delay effects shows the experimental data with more adequacy as indicated by low values of MSE (Table 2) compared with other models. This study found that

TABLE 1 . The estimated parameters for $a, b, \sigma$ and $r$

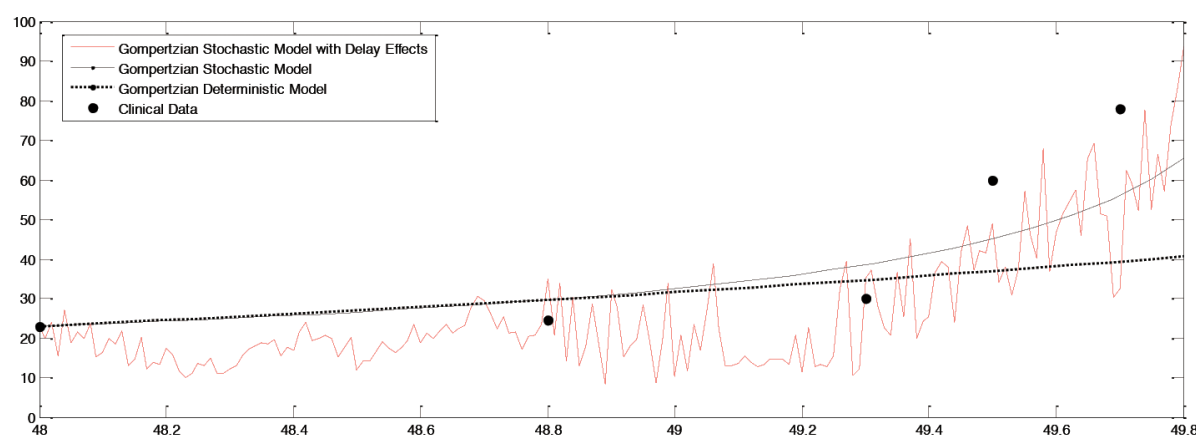

FIGURE 1. Simulation results of Gompertzian stochastic model with delay effects, Gompertzian stochastic model, Gompertzian deterministic model and actual data

TABLE 2. MSE of Gompertzian stochastic model with delay effects, Gompertzian stochastic model and Gompertzian deterministic model

\begin{tabular}{lc}
\hline Mathematical Model & MSE \\
\hline Gompertzian stochastic model with delay effects & 0.0884 \\
Gompertzian stochastic model & 0.6829 \\
Gompertzian deterministic model & 10.0814 \\
\hline
\end{tabular}


the cervical cancer growth can be better presented and understood via Gompertzian stochastic model with delay effect.

\section{ACKNOWLEDGEMENTS}

We would like to thank the Ministry of Education (MOE), Malaysia and Research and Innovation Department, University Malaysia Pahang (UMP) for their financial supports through FRGS Vote No: RDU130122, RACE Research Grant Vote No: RDU121303 and UTM RACE Research Grant Vote No: Q.J130000.3026.00M08. We also would like to thank the Director General of Health Malaysia for giving the permission to publish this paper.

\section{REFERENCES}

American Cancer Society. 2014. Cancer Facts \& Figures 2014. Atlanta: American Cancer Society.

Byrne, H.M. 1997. The effect of time delays on the dynamics of avascular tumor growth. Mathematical Biosciences 144: 83-117

Ferrante, L., Bompadre, S., Possati, L. \& Leone, L. 2000. Parameter estimation in a Gompertzian stochastic model for tumor growth. Biometrics 56: 1076-1081.

Friberg, S. \& Mattson, S. 1997. On the growth rates of human malignant tumors: Implications for medical decision making. Journal of Surgical Oncology 65(4): 284-297.

Guillouzic, S., Ivan, L. \& André, L. 1999. Small delay approximation of stochastic delay differential equations. Physical Review E 59: 3970.

Laird, A.K. 1964. Dynamics of tumour growth. British Journal of Cancer 18(3): 490-502.
Lo, C.F. 2007. Stochastic Gompertz model of tumour cell growth. Journal of Theoretical Biology 248: 317-321.

Lowe, S.W.\& Lin,A.W. 2000.Apoptosis in cancer. Carcinogenesis 21: 485-495.

Mazma Syahidatul Ayuni, M. \& Norhayati, R. 2014. A Gompertzian Model with random effects to cervical cancer growth. International Conference in Mathematics, Engineering and Indusrial Applications (ICoMEIA).

Mohamed, N.F. 2013. Kanser Kedua Ancam Nyawa. Harian Metro. 23 Jun.

Norhayati, R. 2012. Stochastic Runge-Kutta method for stochastic delay differential equations. PhD Thesis, Universiti Teknologi Malaysia (unpublished).

Mazma Syahidatul Ayuni Mazlan, Norhayati Rosli*

\& Nina Suhaity Azmi

Faculty of Industrial Sciences and Technology

Universiti Malaysia Pahang, Lebuhraya Tun Razak

26300 Gambang, Pahang Darul Makmur

Malaysia

Arifah Bahar

UTM Centre for Industrial \& Applied Mathematics (UTM-CIAM)

Universiti Teknologi Malaysia

81310 Johor Bahru, Johor Darul Takzim

Malaysia

*Corresponding author; email: norhayati@ump.edu.my

Received: 28 November 2014

Accepted: 11 March 2015 